\title{
Some Factors Affecting Earnings of Business and Professional Women
}

\author{
By Margaret Elliott, Ph.D. \\ Assistant Professor, Personnel Management, School of Business Administration, University of \\ Michigan \\ and
}

Grace E. Manson, Ph.D.

Research Associate, School of Business Administration, University of Michigan

$\mathrm{T}$ THERE is an admitted lack of factual material on the economic status of women at the higher occupational levels. How much do they earn? With what success, measured in earnings, are they venturing into the "newer" occupations for women? How important is work experience as a factor in earnings? Do collegetrained women receive higher salaries than others? Answers to these questions, and many more which suggest themselves, are as yet in the realm of conjecture.

To meet this need for quantitative data on the status of women in business and professional work, a coöperative study was launched a little more than two years ago by the Bureau of Business Research at the University of Michigan and the National Federation of Business and Professional Women's Clubs, an organization of approximately 50,000 women in forty-seven different states. The Bureau of Business Research has assumed responsibility for financing and directing the investigation, and the Federation has made available the data through the use of questionnaires distributed among its membership. As the study has not yet been completed, the results presented here must be considered in the nature of a preliminary report. A complete analysis of the data will appear shortly as one of a series of
Michigan Business Studies, published by the University of Michigan. Here we must content ourselves with a necessarily brief discussion of some of the more significant causal factors in earnings of business and professional women.

The methods used in making the study are of concern here only as they furnish a basis for evaluating the results. The investigation was based upon an eight-page questionnaire sent to the entire membership of the Federation; 46,760 blanks were distributed through 813 local clubs, of which number 14,073 , or 30 per cent, were filled out in sufficient detail to be usable. It is necessary to bear in mind the limitations of data assembled by means of a questionnaire, even when secured under conditions as favorable as in the present situation. Persons who voluntarily answer a questionnaire constitute a selected group, although the exact basis of selection is not certain. Loyalty to the Federation, interest in the problem under investigation, facility in filling out questionnaires, are certainly among the obvious influences. As a selective factor, occupation engaged in was in this case apparently of relatively little importance, for the distribution of occupations in the group of 14,073 , who returned their questionnaires, varied only very slightly from occupational 
distribution of the entire Federation. After careful comparison with the federal census of occupations, it seems fair to say that the group under investigation is a representative crosssection of women's work, exclusive of manual occupations.

Interest in a study of this sort naturally centers around earnings as a measure of success. "Earnings" were here taken to mean returns from major, full-time occupation, whether in the form of salary or net business earnings (as defined in directions for filling in the questionnaire). Among the personal-history items associated with earnings, which have been analyzed, are occupation-taken individually and also grouped by fields of employment and types of work-experience, age, population of the city or town where employed, marital status, responsibility for dependents, and education. Of these, probably the most important single relationship to be considered is that of occupation to earnings. The wide range of occupations represented in the present study, however, makes it impossible, within the limits of this article, to consider occupations in- dividually. In the 14,073 questionnaires returned, there were listed no less than 6,448 different combinations of jobs and employers. We shall, therefore, confine our discussion here to a comparison of earnings by occupational groups, first, when other influences are not taken into consideration, and second, when certain of these other possible causal factors in earnings are controlled.

\section{Earnings of Business and Profes- SIONal Women by OCCUPational Groups}

A dual scheme of classification for occupations was used in the study. First, occupations were divided into eight groups on the basis of field of employment-that is, the nature of the business, industry or organization where the work was carried on; then they were regrouped according to the nature of the work itself, as clerical, sales, personnel, and so on. An illustration will make clear the difference between the two groupings. Under the first scheme, physicians would be classified under Education if in public school work, under Government if

TABLE I-Comparison of Earnings and Experience by Frelds of Employment

\begin{tabular}{|c|c|c|c|c|c|c|c|}
\hline \multirow{2}{*}{ Field of Employment } & \multirow{2}{*}{$\begin{array}{l}\text { Number } \\
\text { of Cases }\end{array}$} & \multirow{2}{*}{$\begin{array}{l}\text { Per Cent } \\
\text { of Total }\end{array}$} & \multicolumn{3}{|c|}{ Earnings * } & \multirow{2}{*}{$\mid \begin{array}{c}\text { Per Cent } \\
\text { Earning } \\
\$ 3,000 \\
\text { and Over }\end{array}$} & \multirow{2}{*}{$\begin{array}{c}\text { Median } \\
\text { Experi- } \\
\text { ence in } \\
\text { Years }\end{array}$} \\
\hline & & & $Q_{\mathrm{I}}$ & Median & $Q_{3}$ & & \\
\hline Commerce. & 4,743 & 35.7 & $\$ 1,065$ & $\$ 1,436$ & $\$ 1,849$ & 8.2 & 13.7 \\
\hline Education... & 3,088 & 23.2 & 1,253 & 1,558 & 1,949 & 3.7 & 13.3 \\
\hline Manufacture. & 1,922 & 14.4 & 1,216 & 1,554 & 1,999 & 7.2 & 14.4 \\
\hline Government. . . & 1,194 & 9.0 & 1,336 & 1,803 & 2,150 & 5.3 & 14.8 \\
\hline Professional. . & 1,021 & 7.7 & 1,194 & 1,554 & 2,046 & 11.8 & 12.5 \\
\hline Semi-public $\dagger \ldots$ & 831 & 6.2 & 1,529 & 1,854 & 2,269 & 7.3 & 14.6 \\
\hline Transportation. & 448 & 3.4 & 1,197 & 1,435 & 1,683 & 2.3 & 12.8 \\
\hline Primary production. & 55 & .4 & 1,233 & 1,750 & 2,200 & 10.4 & 13.2 \\
\hline Information missing . & 771 & & 1,077 & 1,470 & 1,922 & 6.9 & 13.8 \\
\hline Totals. . & 14,073 & 100.0 & $\$ 1,213$ & $\$ 1,548$ & $\$ 2,038$ & 6.7 & 13.7 \\
\hline
\end{tabular}

* Figured on $\$ 100$ class intervals.

$\dagger$ Civic, eleemosynary and fraternal organizations. 
connected with a city health department, and under Professional if engaged in private medical practice. In the second scheme, where the basis of classification is type of work, all physicians would be grouped together with other health workers under Health. If interest centers in comparison of opportunities in different fields of employment, the first grouping is used; but if one is concerned primarily with the job itself, or kinds of work, then the second is more significant.

Classification by fields of employment reveals a marked concentration in commerce, education, and manufacture (Table I). Approximately onethird of the total number of women represented are in commerce; and commerce, education, and manufacture together command the services of 9,753 , or 73.3 per cent of the total. With the exception of primary production, however, the other groups are probably sufficiently large to show definite tendencies.

There is a marked difference in range of earnings in these different fields. If one compares the spread of earnings of the middle 50 per cent of cases in each field of employment (that is, the difference between $Q_{1}$, the 25th percentile, and $Q_{3}$, the 75 th percentile), it appears that the range of earnings for women in transportation, commerce, education, and manufacture, is noticeably lower than for those engaged in government or professional

TABLE II-Comparison of Earnings and Experience by Types of Work

\begin{tabular}{|c|c|c|c|c|c|c|c|}
\hline \multirow{2}{*}{ Type of Work } & \multirow{2}{*}{$\begin{array}{l}\text { Number } \\
\text { of Cases }\end{array}$} & \multirow{2}{*}{$\begin{array}{l}\text { Per Cent } \\
\text { of Total }\end{array}$} & \multicolumn{3}{|c|}{ Earnings * } & \multirow{2}{*}{$\begin{array}{c}\text { Per Cent } \\
\text { Earning } \\
\$ 3,000 \\
\text { and Over }\end{array}$} & \multirow{2}{*}{$\begin{array}{l}\text { Median } \\
\text { Experi- } \\
\text { ence in } \\
\text { Years }\end{array}$} \\
\hline & & & $Q_{1}$ & Median & $Q_{3}$ & & \\
\hline Clerical. . & 5,862 & 42.8 & $\$ 1,161$ & $\$ 1,467$ & $\$ 1,830$ & 2.6 & 12.4 \\
\hline Teaching. & 2,689 & 19.7 & 1,253 & 1,557 & 1,965 & 4.0 & 13.6 \\
\hline Sales and publicity & 1,469 & 10.8 & 1,019 & 1,531 & 2,220 & 15.2 & 16.4 \\
\hline Health . . . . . . . & 894 & 6.5 & 1,382 & 1,836 & 2,418 & 14.1 & 13.3 \\
\hline Financial. & 609 & 4.5 & 1,511 & 1,864 & 2,498 & 17.7 & 16.9 \\
\hline $\begin{array}{l}\text { Production and planning } \\
\text { Food, living and per- }\end{array}$ & 463 & 3.4 & 968 & 1,295 & 1,870 & 8.3 & 15.5 \\
\hline sonal service. . . . . . . & 418 & 3.1 & 1,219 & 1,860 & 2,494 & 13.7 & 13.8 \\
\hline Welfare . . . . . . . $\ldots$ & 315 & 2.3 & 1,664 & 1,911 & 2,434 & 7.0 & 15.6 \\
\hline Library $\ldots \ldots \ldots \ldots$ & 205 & 1.5 & 1,230 & 1,621 & 2,458 & 5.5 & 16.2 \\
\hline Legal and protective... & 182 & 1.3 & 1,356 & 1,843 & 2,517 & 18.2 & 14.9 \\
\hline Editorial $\ldots \ldots \ldots \ldots$ & 168 & 1.2 & 1,192 & 1,564 & 2,030 & 7.7 & 13.4 \\
\hline Purchasing. . . . . . . . & 141 & 1.0 & 1,061 & 1,368 & 1,888 & 5.8 & 18.3 \\
\hline Research..... & 80 & .6 & 1,550 & 1,900 & 2,225 & 5.1 & 10.3 \\
\hline Personnel. . . . . . . . . . . & 75 & .5 & 1,690 & 2,066 & 2,662 & 21.6 & 16.5 \\
\hline Service............. & 45 & .3 & 2,012 & 2,483 & 2,975 & 24.4 & 17.8 \\
\hline $\begin{array}{r}\text { Professional, not else- } \\
\text { where classified...... }\end{array}$ & 34 & .3 & 1,025 & 1,350 & 2,017 & 6.7 & 12.9 \\
\hline Religious........... & 18 & .1 & 1,000 & 1,275 & 1,900 & $\ldots$ & 18.8 \\
\hline $\begin{array}{l}\text { Administrative, not else- } \\
\text { where classified ...... }\end{array}$ & 12 & .1 & 1,575 & 3,025 & 4,225 & 54.5 & 15.0 \\
\hline Amusements. . . . . . . . . & 7 & .0 & $\cdots$ & $\cdots \cdots$ & $\cdots \cdots$ & $\ldots$ & $\ldots$ \\
\hline Political ........... & $\mathcal{Z}$ & .0 & & $\cdots \cdots$ & & & \\
\hline Information missing . . . & 385 & $\cdots \cdots$ & 1,062 & 1,515 & 2,046 & 10.8 & 19.5 \\
\hline Totals..... & 14,073 & 100.0 & $\$ 1,213$ & $\$ 1,548$ & $\$ 2,038$ & 6.7 & 13.7 \\
\hline
\end{tabular}

* Figured on $\$ 100$ class intervals. 
work, or in semi-public organizations, which include civic, eleemosynary, and fraternal groups. The low range in transportation may be explained by the high percentage of telephone operators and clerical workers included in the group. The range in commerce and manufacture is also considerably lowered by the inclusion of large numbers of clerical workers. This does not apply, however, to education. Furthermore, if one turns from middle range to upper extremes, the comparison is even more distinctly to the disadvantage of education, for in the latter only 3.7 per cent of the group are earning over $\$ 3,000$, whereas, in commerce and manufacture, the percentages of earnings over $\$ 3,000$ are 8.2 and 7.2 respectively. In other words, the apparent chances of high financial rewards in commerce and manufacture are approximately twice as great as in education.

The highest central range in earnings in any group is to be found in semipublic organizations. Here the middle 50 per cent of the total number are earning between $\$ 1,529$ and $\$ 2,269$. This is due in part to the fact that there are relatively few clerical workers in the group. By contrast, the professional group includes not only independent professional workers, such as physicians, lawyers, and architects, but also their office assistants. Similarly in government service, clerical workers are fairly numerous, tending to lower the earnings range. As one might expect, government service seems to offer relatively slight prospects of high returns.

\section{Earnings of Business and Profes- sional Women by Types of Work}

A more significant analysis is secured by a comparison of numerical concentration and earnings in different types of work (Table II). Of the total group under investigation, 5,862 or 42.8 per cent were engaged in clerical work, and 2,689 or 19.7 per cent in teaching. Of twenty different types of work, four-namely, clerical, teaching, sales and publicity, and health work-command the services of 10,914 or 79.8 per cent of all those reporting. Among the types of work where the range of earnings of the middle 50 per cent of the cases is particularly narrow, we find clerical work and teaching. On the other hand, a relatively wide spread is found in food, living, and personal service, library work, and sales and publicity. Again, the percentages of earnings in excess of $\$ 3,000$ are low in clerical work, teaching, and purchasing, in contrast to high percentages in legal and protective, financial, and sales and publicity work.

\section{Relation of Earnings to EXPERIENCE}

Before drawing conclusions, however, the reader should examine the last column in Table II, which indicates median experience in years. Experience, it will be seen, varies widely between groups, from a median of 10.3 years in research to 18.8 years in religious work. How much of the variation in earnings is due to difference in experience? Will occupations maintain independent earnings curves when experience is controlled?

To answer these questions each occupational group has been divided into five-year experience groups and median earnings figured for each experience interval (Table III). Earnings were here distributed on a $\$ 200$ interval instead of the $\$ 100$ interval used in Tables I and II, which explains the lack of agreement between median earnings in these tables. When these curves of median earnings in different types of work are plotted, certain rather definite tendencies are revealed. First, 


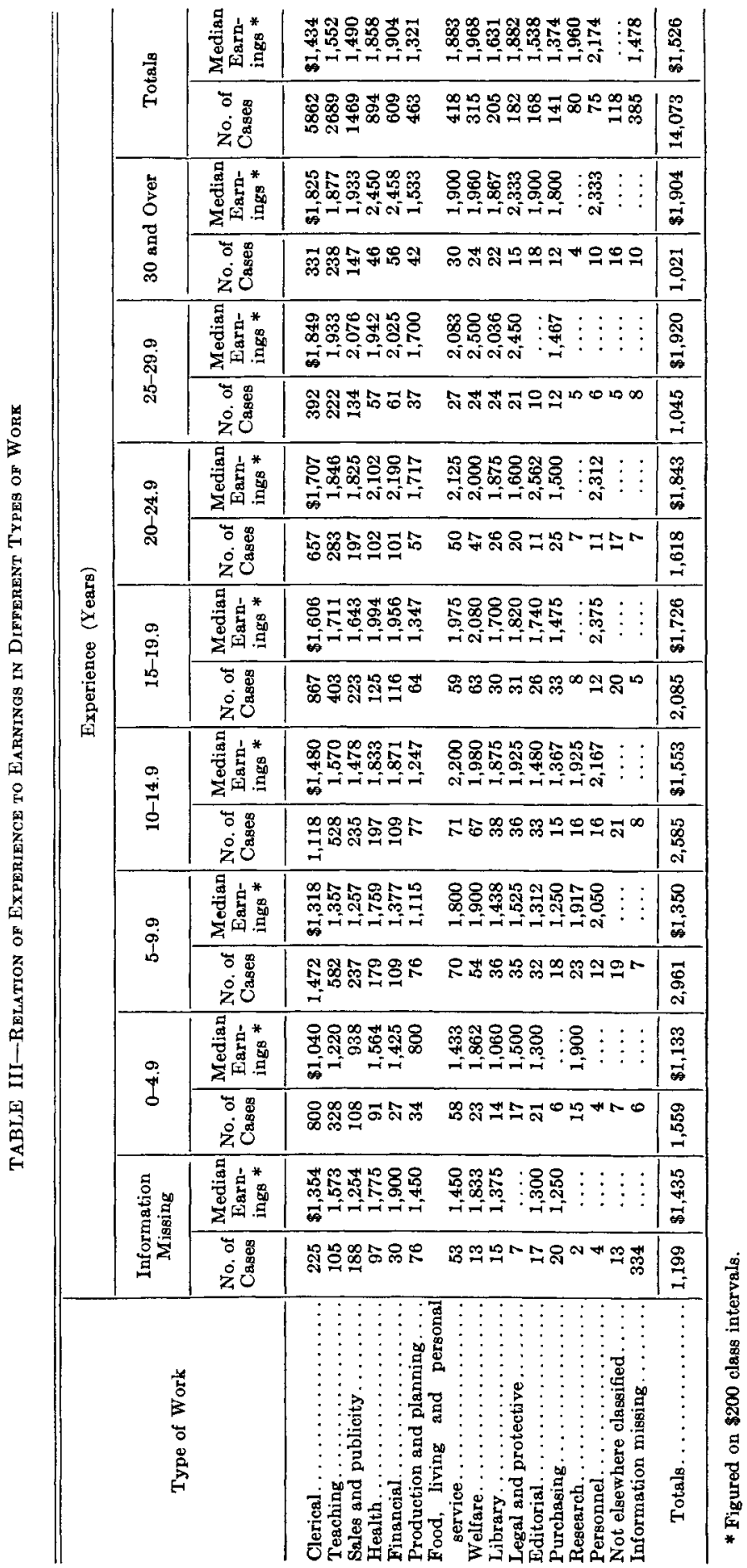


there is a general tendency for earnings to rise with experience up to about thirty years of experience and then to maintain a plateau, or decline. Second, there is a wide difference in initial salaries in various types of work. Third, types of work which have high beginning salaries maintain a generally high level throughout. Fourth, in types of work where the limits of earnings are determined more by individual initiative and ability than by salary schedules, such as selling, law or medicine, earnings are low at the start, but rise with experience to greater heights than in salaried occupations.

\section{Size of the City or Town IN Relation to Earnings}

As might be expected, earnings vary directly with the size of the city or town where the occupation is carried on. Although Table IV shows only comparison of earnings in different types of work by educational levels. From this table it appears: First, that for the total group the better educated women are earning more despite a smaller number of years' experience. Second, that this condition exists in practically all types of work. In other words, the better educated women are in all types of work receiving the highest financial returns in those fields.

Educational concentration varies characteristically in different types of work. This is apparent from a comparison of the percentage distribution by educational levels for the total group with that of the different kinds of work. Of the total group, 11.2 per cent are at the grade school level, 49.4 per cent have attended or graduated from high school, 12.6 per cent have attended normal school, 14.2 per cent have attended college, but have not graduated, and 12.6 per cent hold

Table IV-Relation of Population to Earninga

\begin{tabular}{|c|c|c|c|c|c|c|c|c|c|c|}
\hline & \multicolumn{10}{|c|}{ Population } \\
\hline & $\begin{array}{l}\text { Infor- } \\
\text { mation } \\
\text { Missing }\end{array}$ & $\begin{array}{l}\text { Less } \\
\text { than } \\
2,500\end{array}$ & $\begin{array}{r}2,500- \\
4,999\end{array}$ & $\begin{array}{r}5,000- \\
9,999\end{array}$ & $\begin{array}{r}10,000- \\
24,999\end{array}$ & $\begin{array}{r}25,000- \\
49,999\end{array}$ & $\begin{array}{r}50,000- \\
99,999\end{array}$ & $\begin{array}{l}100,000- \\
249,999\end{array}$ & $\begin{array}{c}250,000 \\
\text { and } \\
\text { Over }\end{array}$ & Totals \\
\hline $\begin{array}{l}\text { Number of cases. } \\
\text { Median earnings * }\end{array}$ & $\begin{array}{l}\mathbf{5} \\
\cdots\end{array}$ & $\begin{array}{r}1,055 \\
\$ 1,252\end{array}$ & $\begin{array}{r}1,853 \\
\$ 1,295\end{array}$ & $\begin{array}{r}2,484 \\
\$ 1,345\end{array}$ & $\begin{array}{r}3,219 \\
\$ 1,486\end{array}$ & $\begin{array}{r}1,969 \\
\$ 1,748\end{array}$ & $\begin{array}{r}1,454 \\
\$ 1,824\end{array}$ & $\begin{array}{r}1,121 \\
\$ 1,935\end{array}$ & $\begin{array}{r}913 \\
\$ 2,151\end{array}$ & $\begin{array}{l}14,073 \\
\$ 1,526\end{array}$ \\
\hline
\end{tabular}

* Figured on $\$ 200$ intervals.

the population distribution for the total group, the same general tendency for earnings to increase with size of place holds for each different type of work.

\section{Earnings in Different Trpes of Work by Educational Levels}

In comparing earnings in different kinds of work (Table II), one important causative factor, namely possible differences in education of persons engaged in these occupations, was not considered. Table $\mathrm{V}$ makes possible a
B.A. or advanced degrees. Comparing these total group percentages with those for different fields, interesting variations appear. There is, for instance, a noticeable concentration of women of only high school education in clerical and financial work. Teaching, on the other hand, claims a high percentage of college graduates, nongraduates, and normal school women. Sales and publicity, production and planning, and purchasing, include considerably higher proportions of women at the grade school level. 


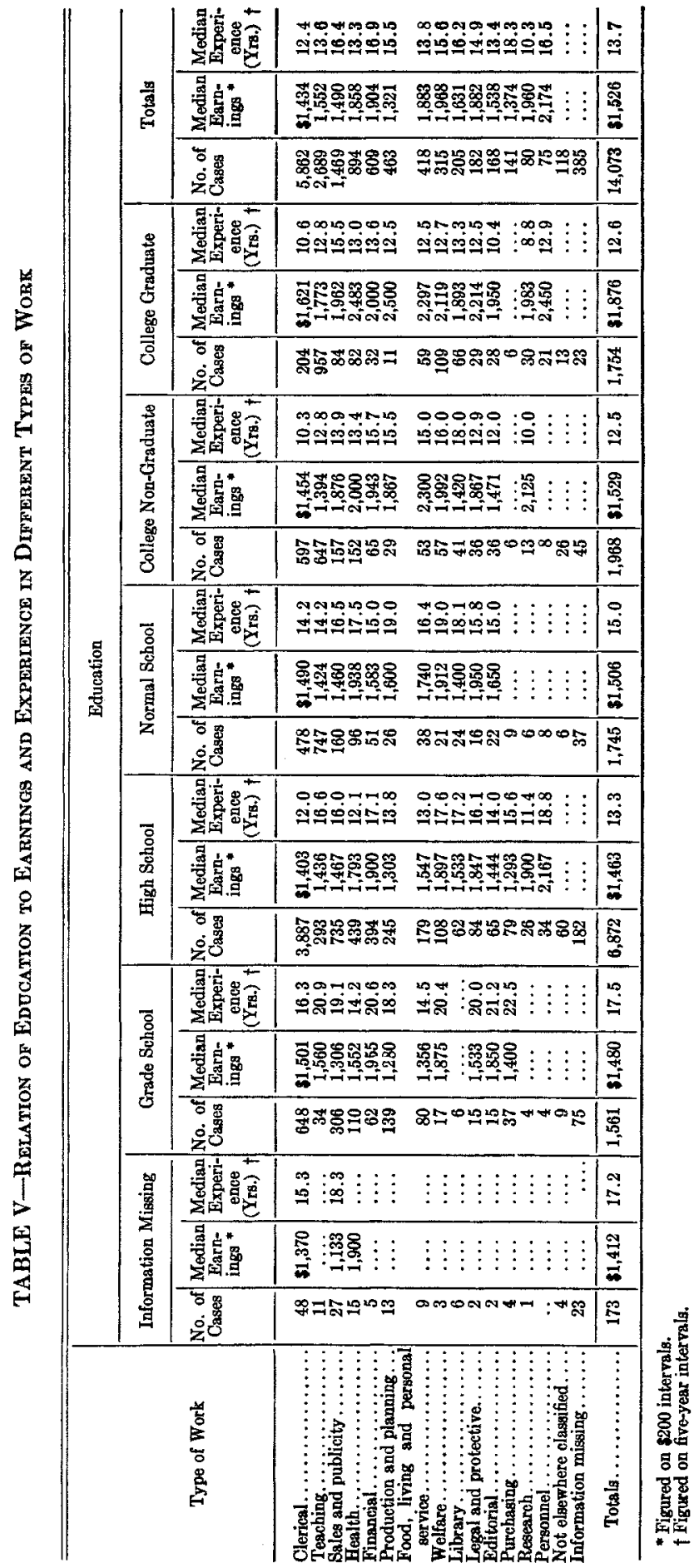


From Table $V$ it is apparent that in every field of work the college woman is earning more than the non-college woman. But is she venturing into those fields where chances of high financial rewards are greatest? Of the 1,725 college women giving necessary information, 55.5 per cent are engaged in teaching, 11.8 per cent in clerical work, and 6.3 per cent in welfare work. Of these, only the last offers, relatively speaking, much remunerative promise. (See Table II.)

Seventy per cent of the college group are in the employ of educational, social, or welfare organizations. Why? A variety of possible explanations suggest themselves. Is the college woman financially more nearly able to disregard monetary considerations than women at lower educational levels? Is the question of financial rewards of less significance to her than the inherent satisfactions of the work itself? May it be that the college woman is more susceptible to the influence of traditional respectability surrounding certain occupations such as teaching and social work? Or is the matter of ease of securing employment a controlling factor? The question of causative factors deserves consideration.

\section{Summary}

The earnings of 14,073 business and professional women have been analyzed in an attempt to isolate some of the factors influencing earnings. From this analysis the following conclusions have been drawn:

(1) Earnings vary widely in the different fields of employment. Median earnings are apparently lowest in the fields of commerce and transportation and highest in government service and in civic, eleemosynary, and fraternal organizations (grouped here under "semi-public"). Chances of high financial rewards seem best in inde- pendent professional work, commerce, manufacture, and semi-public organizations, and poorest in transportation and education.

(2) Type of work done is a more significant basis for comparing earnings than field of employment, for interest is centered in the occupation itself rather than in the place of work or nature of employer's business. The largest single group is the clerical workers, which includes 5,862 or $\mathbf{4 2 . 8}$ per cent of the total. There are, however, more than 500 women in each of the following kinds of work: clerical, teaching, sales and publicity, health, and finance. Median earnings are higher in health and financial work than in teaching, clerical, or sales and publicity work. Furthermore, the percentages of women earning $\$ 3,000$ or more in clerical work and teaching are relatively small-2.6 per cent and 4.0 per cent respectively.

(3) In each type of work, earnings vary with years of experience. In general, earnings increase with experience up to approximately thirty years of work and then decline. Median earnings of women with less than five years' experience are lowest in production and planning, sales and publicity, and clerical work. They are highest in the following groups: Welfare, legal and protective work, finance, and food, living and personal service. Earnings after twenty years of experience are highest for these same groups.

(4) Median earnings vary directly with population of towns where the women are working. How much of this variation is due to differences in cost of living, and how much to other selective factors, it is difficult to say. In types of work where the number of cases is sufficiently large to warrant conclusions, there are wide differences in earnings between large and small population centers. This is particu- 
larly true of legal and protective and be explained either by the small numfinancial workers. For clerical work- ber of cases or by the lower experience ers, on the other hand, earnings vary median of college women in the rerelatively little according to the size of search group. It seems, therefore, the community.

(5) Almost without exception, median earnings increase with the amount of education received. College graduates are the most highly paid group in every type of work except research. This exception can probably that where college women venture they succeed. But so far they tend to concentrate in teaching, where salaries are relatively low. Seventy per cent of the college group are in the employ of educational, social, or welfare organizations. 